\title{
Mesenchymal Stem/Stromal Cells in Regenerative Medicine: Can Preconditioning Strategies Improve Therapeutic Efficacy?
}

\author{
Richard Schäfer $^{\mathrm{a}}$ Gabriele Spohn $^{\mathrm{a}}$ Patrick C. Baer ${ }^{\mathrm{b}}$ \\ ${ }^{a}$ Institute for Transfusion Medicine and Immunohematology, German Red Cross Blood Donor Service Baden-Württemberg-Hessen \\ gGmbH, Goethe University Hospital, Frankfurt/M., Germany; \\ bDivision of Nephrology, Department of Internal Medicine III, Goethe University, Frankfurt/M., Germany
}

\section{Keywords}

Bone marrow . Stem cell transplantation - Stem cells . Stroke

\section{Summary}

Mesenchymal stem/stromal cells (MSCs) are becoming increasingly important for the development of cell therapeutics in regenerative medicine. Featuring immunomodulatory potential as well as secreting a variety of trophic factors, MSCs showed remarkable therapeutic effects in numerous preclinical disease models. However, sustainable translation of MSC therapies to the clinic is hampered by heterogeneity of MSCs and non-standardized in vitro culture technologies. Moreover, potent MSC therapeutics require MSCs with maximum regenerative capacity. There is growing evidence that in vitro preconditioning strategies of MSCs can optimize their therapeutic potential. In the following we will discuss achievements and challenges of the development of MSC therapies in regenerative medicine highlighting specific in vitro preconditioning strategies prior to cell transplantation to increase their therapeutic efficacy.

(c) 2016 S. Karger GmbH, Freiburg

\section{Introduction}

More than four decades ago Alexander Friedenstein identified bone marrow(BM)-derived fibroblastoid clonogenic cells that sup- ported hematopoiesis and showed multipotent differentiation capacity $[1,2]$. In the following years, being depicted as 'mesenchymal stem/stromal cells' (MSCs), in particular their differentiation potential and 'stemnesss' suggested the potential applicability of MSCs in a field that later became regenerative medicine. To date, MSCs have been isolated and characterized from a great variety of postnatal organs such as bone, BM, periosteum, synovial membrane/fluid, adipose tissue (AT), skeletal muscle, skin, periodontium and pancreatic islets, as well as from prenatal tissues like umbilical cord (blood) (UC(B)), amniotic fluid (AF) and placenta [3-7].

Numerous studies investigating in the multipotentiality of MSCs emphasized the capability of MSCs to differentiate not only in vitro and in vivo into adipogenic, osteogenic, chondrogenic, endothelial and myogenic lineages [8-14], but also into epithelial [15, $16]$ and neural cell types $[17,18]$. There is growing scepticism about functional differentiation capacities of MSCs beyond adipocytes, osteocytes, and chondrocytes [19-21]. Yet, evidence of therapeutic capacities of MSCs in animal studies, modeling diseases such as stroke, myocardial ischemia or diabetes [22-24], raised great expectations that MSCs could be used as 'multi-talent cell source' for cell therapeutics with broad clinical applicability. Promising early clinical proof-of-concept studies for treatment of graftversus-host disease [25-28] and regenerative applications [23, 29] appear to point towards this direction yet. Nevertheless, we are still waiting for the sustainable translation of MSC therapies to the clinic.

In the following, we will discuss achievements and challenges of the development of MSC therapies in regenerative medicine, highlighting specific in vitro preconditioning strategies prior to cell transplantation to increase their therapeutic efficacy.

\section{KARGER}

Fax +497614520714

\section{() 2016 S. Karger GmbH, Freiburg}

$1660-3796 / 16 / 0434-0256 \$ 39.50 / 0$ 
Table 1. Most frequent conditions for MSCs therapies clinical trials

\begin{tabular}{|c|c|c|c|c|}
\hline Source of MSCs & Condition & $\begin{array}{l}\text { Total number of } \\
\text { clinical trials }\end{array}$ & Autologous & Allogeneic \\
\hline \multirow{7}{*}{ BM-MSCs } & Ischemia ${ }^{*}$ & 28 & 21 & 8 \\
\hline & Bone regeneration & 18 , thereof $9 \mathrm{TE}^{\#}$ & 14 & 3 \\
\hline & Graft rejection & 12 & 4 & 9 \\
\hline & Degenerative diseases ${ }^{\S}$ & 12 & 9 & 2 \\
\hline & Lung diseases ${ }^{\dagger}$ & 9 & 3 & 6 \\
\hline & Multiple sclerosis & 9 & 9 & 0 \\
\hline & Amyotrophic lateral sclerosis & 3 & 3 & 0 \\
\hline \multirow[t]{7}{*}{ AT-MSCs } & Ischemia* & 10 & 6 & 2 \\
\hline & Degenerative diseases ${ }^{\S}$ & 8 & 7 & 1 \\
\hline & Crohn's disease & 3 & 1 & 2 \\
\hline & Spinal cord injury & 2 & 2 & 0 \\
\hline & Liver cirrhosis & 2 & 2 & 0 \\
\hline & Multiple sclerosis & 2 & 2 & 0 \\
\hline & Amyotrophic lateral sclerosis & 2 & 1 & 1 \\
\hline BM-MSCs & GvHD & 23 & 1 & 20 \\
\hline AT-MSCs & GvHD & 3 & 1 & 2 \\
\hline \multicolumn{5}{|c|}{$\begin{array}{l}{ }^{*} \text { Including myocardial infarction, stroke, and critical limb ischemia. } \\
{ }^{\#} \text { Tissue engineering, e.g. MSCs seeded on bioceramic plates or immobilized in allogeneic bone prior to } \\
\text { implantation. } \\
\text { se.g. osteoarthritis, degenerative disc disease. } \\
\text { †e.g. emphysema, respiratory distress syndrome. }\end{array}$} \\
\hline
\end{tabular}

\section{The Heterogeneity of MSCs and Non-Standardized ex vivo Culture Technologies}

In the human bone and $\mathrm{BM}$, which are currently a major source for MSC therapeutics (table 1), MSC subpopulations, such as fibroblastoid reticular stromal cells, adipose stromal cells, round stromal cells and bone lining cells, reside in distinct microanatomical localizations [30]. In addition, the perivascular niche harbors cells featuring MSC phenotypes as shown for various organs $[4,30,31]$. Due to the low frequency of MSCs in the BM (below $0.1 \%$ of nucleated cells [32]), manufacturing substantial numbers of MSC doses for therapeutic applications requires isolation/enrichment of MSCs as well as their in vitro expansion.

Currently, it is unclear how in detail, most importantly on functional level, the in vivo heterogeneity of MSCs is reflected by their in vitro culture, i.e. if, and if yes to which extent, different MSC phenotypes feature different functional properties. The most widely used MSC isolation and expansion technique is sub-culturing adherent cells from BM mononuclear cell fraction, enriched by density gradient [33], or from the stromal vascular fraction (SVF), obtained by enzymatic treatment of lipoaspirate [6]. These procedures, or alternative isolation techniques such as collagen and fibrin matrices or specific culture conditions (e.g. low oxygen, media enriched with growth factors), may select for certain MSC subpopulations and/or promote their in vitro expansion $[34,35]$. In addition to considerable donor-donor variations, BM- and AT-MSC preparations feature significant heterogeneity in vitro as shown by a highly variable expression profile of marker sets potentially de- fining MSC subpopulations, e.g. CD140a, CD146, CD200, CD201, or CD271 $[33,36]$. In addition, CD106 and CD271 expression is dynamic (decreasing) during the course of MSC in vitro culturing [35]. In contrast, CD73, CD90, and CD105 feature high and stable expression of MSCs in vitro, and therefore, together with a tri-lineage differentiation capacity and absence of hematopoietic markers, were elected by the International Society of Cell Therapy (ISCT) to characterize human MSC preparations [8].

Another variable to be considered for the development of MSC therapies is the influence of so far only poorly defined blood components such as human platelet lysate (HPL) used for media supplementation. Compared to fetal bovine serum, media supplemented with HPL or other human blood components are superior for the growth promotion and differentiation potential of MSCs [37-39]. Further studies are required to assess a possible influence of human blood components on the therapeutic efficacy of MSCs but also their potential immunogenicity.

\section{Possible Implications of MSC Heterogeneity on Their Regenerative Potential}

To address the question whether or not, and if yes to what extent, the heterogeneity of MSCs might affect their therapeutic potential in regenerative medicine,in the following, we will discuss the variables source and subpopulations with respect to the MSC function.

Given their multipotentiality, it might be obvious to focus on the differentiation potential of MSCs in order to assess its function 
pertinent to tissue regeneration. However, this approach poses several challenges: first, how to assess MSC differentiation on a functional level, and second, how to translate observations of in vitro differentiation to the ultimately relevant regenerative setting in vivo.

Detection of markers such as glial fibrillary acidic protein, nestin, synaptophysin or $\beta$ tubulin III/Tuj1 by 'neurogenic' differentiated MSCs $[17,18,40]$ without evidence of neurotransmitter-modulated neuron-specific electrophysiological properties might not be sufficient to prove the neurogenic differentiation capacity of MSCs [19]. The limited applicability of 'lineage-specific markers' to assess MSC differentiation also refers to the numerously claimed cardiomyogenic differentiation potential of MSCs. Specifically native MSCs have been shown to express 'cardiomyogenic markers' (e.g. troponin I or atrial natriuretic protein), as well as MSCs after treatment with differentiation media, without featuring functional myogenic properties (e.g. formation of contractile cell structures) [21, 41]. Yet, given the heterogeneity of MSCs and our still limited understanding of the biology of MSCs, the existence of probably rare MSC subpopulations featuring true transdifferentiation potential could not completely be ruled out at this point, in particular as MSC differentiation is a clonal event [21, 42].

Regarding influence of source, UCB-MSCs had impaired adipogenic differentiation potential compared to AT-MSCs, BM-MSCs $[6,43]$, and BM-MSCs showed greater osteogenic differentiation potential compared to UCB-MSCs, AT-MSCs, or placenta-derived MSCs [43, 44]. Interestingly, BM-MSCs showed variable osteogenic differentiation potential depending on the harvest technique (reamer/irrigator/aspirator, spoon, fine-needle aspiration) and the anatomical localizations (femur, iliac crest) [45]. Amongst postnatal sources, BM-MSCs appear highly applicable for regeneration of cartilage defects featuring acceptable graft integration and biological similarities to cartilage tissue [46]. Comparing MSCs only from fetal sources, UCB-MSCs showed greater chondrogenic differentiation capacity than MSCs from amniotic fluid [47]. A recent study compared two cell types from the same source (UCB), i.e. UCBmononuclear cells and UCB-MSCs, with cord matrix(CM)-MSCs regarding their therapeutic potential in a rat stroke model. All tested cell types showed therapeutic efficacy; however, more severe complications could be detected in the CM-MSC group [48].

Identification and quantification and/or enrichment of potent MSC subpopulations could mark a significant step towards optimized and standardized MSC therapies for regenerative medicine. Regarding possible differences of regenerative potential between MSC subpopulations, several studies tackled this complex and technically challenging problem. To date, different strategies have been developed to functionally characterize MSC subpopulations and to assign MSC subpopulation phenotypes to function.

First, investigating a substantial number of BM-MSC preparations in vitro, correlation analyses suggested an association of surface markers (CD10, CD71, CD106, CD119, CD146, CD166, and $\mathrm{CD} 271$ ) in order to assess the differentiation and clonogenic potential of BM-MSCs [33]. Another study applied a broad antibody panel (>200 markers) to compare AT-MSC surface after osteogenic or adipogenic differentiation to undifferentiated AT-MSCs. Here, an increased expression of CD164 was associated with an osteogenic differentiation, whereas CD36, CD40, CD146, CD164, and CD271 were higher expressed after adipogenic differentiation [49].

Another correlation concept identified, in addition to gene expression modulation experiments, the transcription factor TWIST1 as being significantly involved in BM-MSC function such as differentiation, support of angiogenesis and immunomodulation. Based on these observations, a 'clinical indication prediction scale' was developed assigning a more pro-angiogenic potential at higher TWIST1 expression to BM-MSCs, whereas a lower TWIST1 expression indicated a more pronounced immunomodulatory function of BM-MSCs [50].

Second, positive selections and subsequent functional analyses of MSC subpopulations could mark a further step forward. However, with the limitations of a potentially decreasing purity during sub-culturing and/or producing 'culture artifacts', as interplay of subpopulations might be relevant for their function, the CD271+ MSC subpopulation is abundant in intramedullary cavities of the long bones, and CD271+ sorted BM-MSCs featured greater osteogenic differentiation potential compared to non-sorted BM-MSCs $[32,51]$. Meanwhile, first steps have been taken towards clinicalgrade GMP production of CD271+ sorted BM-MSCs for bone regeneration [52]. Amongst placenta-derived MSCs, a greater osteogenic differentiation potential could be assigned to the CD146+ subpopulation, whereas, after sorting, CD146- MSCs could not form mineralized extracellular matrix, an indicator for functional osteogenic differentiation [53].

Third, MSC subpopulations may be defined by their 'performance' during in vitro culture, e.g. proliferation potential. A recent study compared BM-MSCs with long-term growth potential ('high growth') with BM-MSCs featuring lower cumulative population doublings and cumulative cell numbers ('low growth'). The study detected differences with respect to their osteogenic differentiation potential in vitro and in vivo. Specifically, 'low growth' BM-MSCs appeared to be more potent in osteogenic differentiation in vitro, whereas in vivo application of 'high growth' BM-MSCs induced larger volumes of ectopic bone in a rodent model [54].

Fourth, novel technologies, such as high-resolution microfluidic single-cell transcriptional profiling, allow clustering of subpopulations within MSC preparations [55]. Applying a combined library of surface markers with targets that are regarded as being indicative for MSC regenerative function, a recent study identified a provascular phenotype within the BM-MSC preparation that might be applicable for regeneration of the brain (stroke), the heart (myocardial infarction) or other clinical indications where improvement of vascularization is needed [56].

\section{MSCs Secrete Trophic Factors and Produce Extracellular Vesicles}

The aforementioned limited evidence of the functional differentiation capacity of MSCs together with the observation that MSCs 
exert regenerative potential even without long-term survival after in vivo transplantation [57] led to the conclusion that trophic factors, released by MSCs, mainly mediate their therapeutic effects [58]. Indeed, various studies confirmed that MSCs produce and secrete a great variety of factors that are supposed to exert regenerative effects $[33,59,60]$ :

- Angiopoietin-1: induction of angiogenesis, promotion of myocytes survival in myocardial infarction, increased survival of implanted MSCs, reduction of infarct size and fibrosis

- Brain-derived neurotrophic factor (BDNF):reduction of infarct size, promotion of neuronal tissue survival and differentiation

- Erythropoietin: angiogenesis, anti-apoptotic effects

- Fibroblast growth factor 1/2/4/7/9 (FGF-1/2/4/7/9): induction of angiogenesis, anti-apoptotic and anti-fibrotic effects, proliferative effects

- Glial cell-derived neurotrophic factor (GDNF): reduction of infarct size and axonal growth, promotion of dopaminergic neurons, motoneurons survival and morphological differentiation

- Granulocyte/macrophage-colony stimulating factor (G/M-CSF): progenitor cell mobilization, anti-apoptotic effects

- Hepatocyte growth factor (HGF): progenitor cell mobilization, induction of angiogenesis, promotion of cell growth, antiapoptotic and anti-fibrotic effects

- Insulin-like growth factor 1/2 (IGF-1/2): progenitor mobilization, induction of renal tubular cells proliferation, anti-apoptotic effects

- Leukemia inhibitory factor (LIF): progenitor cell mobilization

- Nerve growth factor (NGF): neuroprotective effects

- Platelet-derived growth factor (PDGF): proliferative effects

- Stromal cell-derived factor 1 (SDF-1): progenitor cell mobilization

- Secreted frizzled-related protein 2 (Sfrp-2): myocardial survival and repair after ischemic injury

- Stanniocalcin 1 (STC-1): anti-apoptotic effects

- Transforming growth factor $\beta 1 / 2 / 3$ (TGF- $\beta 1 / 2 / 3$ ): stem cell differentiation and protection, tubulogenesis in kidney, antiapoptotic effects

- Vascular endothelial growth factor (VEGF): induction of angiogenesis, stimulation of peritubular capillaries proliferation, progenitor cell mobilization, anti-apoptotic effects.

Interestingly, the secreted factor profile of AT-MSCs appears to be different compared to BM-MSCs [61]. To date, only few studies identified specific trophic factors of MSCs as relevant for regeneration of distinct pathologies (e.g. BDNF for stroke [62-64] and VEGF for myocardial infarction [65]).

There is growing evidence that extracellular vesicles (EVs) released by MSCs contribute to the therapeutic repertoire of the trophic factors of MSCs [66, 67]. Application of MSC-derived EVs has shown efficacy in various animal models such as myocardial infarction, limb ischemia, wound healing, or kidney, liver and lung injury $[68,69]$. Although promising, before a sustainable translation into the clinic as possible alternative to MSC-containing therapeutics, MSC-EVs need to be defined more clearly and to be proven similar or superior with regard to efficacy and safety compared to engrafted MSCs.
The most frequent conditions in regenerative medicine for MSC therapies in clinical trials include ischemia (myocardial infarction, stroke, critical limb ischemia), degenerative diseases (osteoarthritis, degenerative disc disease), and bone regeneration with BMMSCs as the most frequently used source (table 1). Interestingly, in total more MSC clinical trials have been conducted on regenerative medicine therapies than on GvHD.

\section{Concepts of MSC Preconditioning}

As pointed out in the previous section, MSC therapies are promising options to support organ and tissue regeneration. The protective effects of MSCs, their conditioned medium (CM), or MSC-EVs have been shown to support regeneration after various organ and tissue injuries. Yet, transplantation of MSCs or application of MSC$\mathrm{CM}$ or MSC-EVs require MSCs with maximum regenerative capacity. Therefore, the development of new strategies to improve the regenerative efficiency of MSCs is urgently needed. In vitro pretreatment ('preconditioning') strategies can enhance survival, engraftment, and paracrine properties of MSCs and, therefore, optimize their reparative and regenerative capacity. In the following section, we summarize different MSC preconditioning technologies that have been developed in the last decade. Specifically, we focus on preconditioning regimens tested in in vivo disease models, and not only in vitro studies with appropriate animals for control, i.e. animals treated with non-preconditioned cells.

To date, various in vitro preconditioning strategies have been applied to enhance the regenerative capacity of MSCs [59]. MSC preconditioning includes modulation of culture atmosphere (hypoxic or anoxic), 3D culture, addition of trophic factors (growth factors, cytokines, or hormones), lipopolysaccharides, and pharmacological agents. The factors secreted by MSCs in response to the preconditioning regime are manifold and exert immunomodulatory or immunosuppressive anti-apoptotic, pro-angiogenic, and trophic effects [59]. The secretome (or the paracrine profile) of pretreated MSCs varies according to the preconditioning regimen used. Different preconditioning methods either activate or suppress different molecular signals and signal transduction cascades. The cellular responses are complex, and, in most cases, the pretreatment procedure affects a great number of factors, and not only a single, specific molecule or protein. In contrast, it should be mentioned that another approach to enhance the release of a specific regenerative factor is to overexpress a single factor in MSCs [7074]. Nevertheless, these genetically engineered MSCs are not reviewed in this article.

\section{Preconditioning by Environmental Variations}

Several studies showed that preconditioning by hypoxia or anoxia substantially enhanced the regenerative potential of MSCs (table 2) [75-82]. Exposure of MSCs to reduced oxygen partial pressure induced the expression of genes involved in migration 
Table 2. Selected recent studies using preconditioned MSCs in in vivo models ${ }^{\mathrm{a}}$

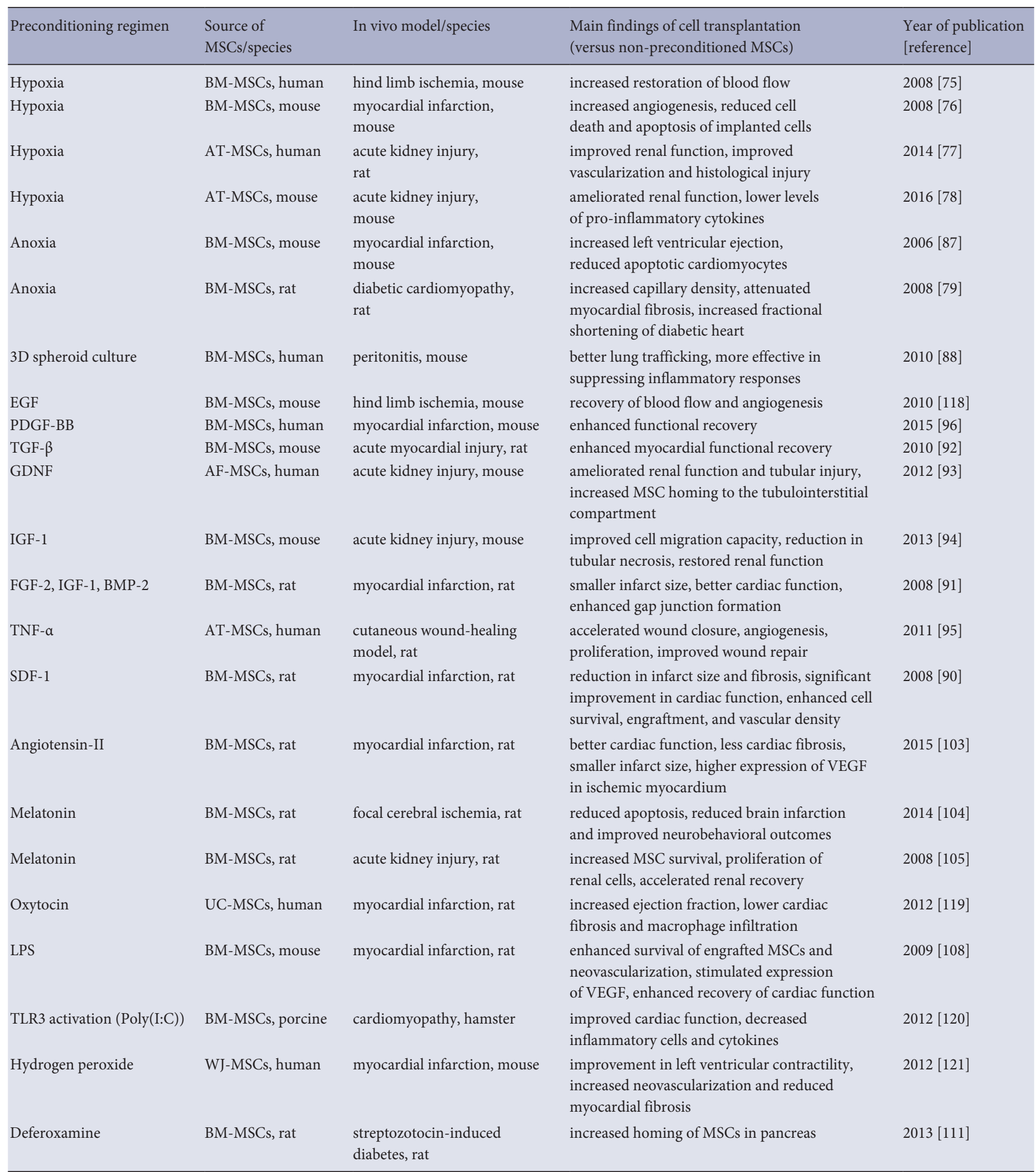

a'We applied a PubMed search using the terms 'preconditioning' and 'mesenchymal stem'. In addition, we only focus on preconditioning regimens tested in in vivo disease models and not simply in vitro studies with appropriate control animals, i.e., animals treated with non-preconditioned cells.

AF-MSCs = Amnion fluid-derived MSCs; AT-MSCs = adipose tissue-derived MSCs; BM-MSCs = bone marrow-derived MSCs; BMP = bone morphogenetic protein; EGF = epidermal growth factor; FGF = fibroblast growth factor; GDNF = glial cell-derived growth factor; IGF-1 = insulin-like growth factor-1; LPS = lipopolysaccharide; PDGF = platelet-derived growth factor; Poly(I:C) = polyinosinic:polycytidylic acid; SDF-1 = stromal cell-derived factor-1; ROS = reactive oxygen species; TGF- $\beta=$ transforming growth factor $-\beta$; TLR = Toll-like receptor; TNF- $\alpha=$ tumor necrosis factor- $\alpha$; VEGF = vascular endothelial growth factor; WJ-MSCs = Wharton`s jelly-derived MSCs. 
and homing (e.g. CXCR4 and SDF-1), mainly regulated by the activity of hypoxia-inducible factor $1 \alpha$ (HIF-1a) [83]. Moreover, the culture of MSCs in a hypoxic environment appears to be more similar to the real in situ setting of MSCs than 'artificial' standard culture conditions $\left(21 \% \mathrm{O}_{2}\right)$ [40]. Notably, the cellular responses to hypoxia in vitro seem to vary between different oxygen concentrations $\left(0.1-5 \% \mathrm{O}_{2}\right)$ (reviewed in [82]).

In vitro preconditioning by hypoxia was shown to stimulate the secretion of growth factors, cytokines, and other proteins and the release of EVs (exosomes and microvesicles) from MSCs [84]. In this case, EVs in turn were also shown to carry a variety of biomolecules such as growth factors, receptors, enzymes, transcription factors, signaling and immunomodulatory molecules, DNA, RNA transcripts, and noncoding RNA including retrotransposons, vault RNA, long non-coding RNAs and microRNAs $[85,86]$.

Hypoxia preconditioning has also been shown to enhance cell survival and proliferation [77, 80-82]. Also, hypoxic pre-incubation of MSCs induced metabolic changes that resulted in higher in vivo cell survival after transplantation [81]. It was also shown that culture in hypoxia enhanced the angiogenic potential of MSCs and improved their survival in both in vitro and in vivo studies [80, 81]. The involved downstream signaling pathways are the translocation of HIF-1a to the nucleus with the activation of gene expression (e.g. VEGF), but also the generation of reactive oxygen species (ROS) and phosphorylation of Akt and MAPK ERK1/2 [82].

The positive in vivo effects of hypoxic preconditioned and systemically applied (i.v.) MSCs have been shown in a rat model of ischemic acute kidney injury [77]. In this study, vascularization, apoptosis, renal injury, and levels of serum creatinine as well as blood urea nitrogen were significantly improved in the group that received preconditioned MSCs compared with the non-pretreated control groups [77]. Also, anoxic preconditioning has been shown to enhance MSC survival and to promote their regenerative capacity [79]. Mechanistically, anoxia-induced increased phosphorylation of cell survival factors such as Akt and endothelial nitric oxide synthase are discussed [87].

A report by Bartosh and coworkers [88] showed that MSCs cultured as 3D spheroids had increased therapeutic potential. Specifically, the investigators used a hanging drop protocol to induce the spheroid formation of MSCs and found that these MSCs expressed the anti-inflammatory protein TNF- $\alpha$-stimulated gene/protein 6 (TSG-6) at very high levels in vitro. Another very interesting result of this study was that larger numbers of the cells trafficked through the lung after infusion and were recovered in spleen, liver, kidney, and heart. The 3D spheroid MSCs were about one-fourth the volume of MSCs from adherent standard cultures, which may explain the enhanced trafficking through the lung [88]. Another study from this group demonstrated that cell activation in $3 \mathrm{D}$ culture also depends critically on the culture medium used [89].

Specifically, the authors described that only chemically defined, xeno-free media supplemented with human serum albumin resulted in compact spheres with high cell viability and high expression of anti-inflammatory (PGE2, TSG-6) and anti-cancer molecules (TRAIL, IL-24) [89].

\section{Growth Factors, Cytokines, Chemokines, Hormones}

In addition to the culture environment, several growth factors or other small molecules were shown to enhance the regenerative capacity of MSCs in vitro. Indeed, the growth factors EGF, GDNF and IGF-1, the pro-inflammatory cytokine TNF- $\alpha$, the chemokine SDF-1 (CXCL12), or hormones such as angiotensin-II have been shown to enhance regenerative capacity or the paracrine functions of MSCs (table 2) [90-98].

Previously, a functional EGF receptor was identified on MSCs with evidence of an active EGF signal transduction [99]. EGF promoted in vitro expansion of MSCs without altering their multipotency $[97,98,100]$, and the effects of EGF on MSC cell motility and migration are also well described [98-100]. Pretreatment of MSCs with EGF enhanced the release of factors such as VEGF, HGF, HBEGF, IL-6, and IL-11, but not FGF-2 [97, 101]. VEGF and HGF play a pivotal role in MSC-mediated accelerated wound healing through inducing angiogenesis and improving oxygen supplies to the ischemic tissues [97]. EGF treatment has also been shown to enhance MSC motility, which is required for repopulation of MSCs within the wound bed [97]. Furthermore, the functional outcome of hind limb ischemia has been shown, most likely due to the delivery of pro-angiogenic factors by MSCs [97].

Herrmann et al. [92] have shown that TGF- $\beta$ increased the VEGF production of MSCs in vitro and, to a greater extent, in combination with TNF- $\alpha$ or hypoxia. VEGF production was upregulated by a p38 MAPK-dependent mechanism and could be suppressed by p38 MAPK inhibition. Furthermore, the investigators infused TGF- $\beta$-preconditioned MSCs immediately before myocardial ischemia/reperfusion injury and could show that the postischemic myocardial functional recovery was improved in hearts infused with preconditioned MSCs compared with untreated MSCs or vehicle.

Treatment with CM derived from TNF- $\alpha$-preconditioned MSCs accelerated wound healing and angiogenesis in vivo [95]. In addition, TNF- $\alpha$-pretreated MSCs increased the release of cytokines, chemokines, and proteases, as shown by proteomic analysis. This study identified the enhanced secretion of 118 proteins into the culture medium upon TNF- $\alpha$ incubation [102]. Specifically, the TNF- $\alpha$-induced secretome of MSCs included many molecules known to be critically involved in inflammatory processes (e.g. IL-6, IL-8, and MCP-1). Inflammation is a key response to tissue injury and is critical for regeneration, with many cytokines being associated with this process. Enhanced expression of IL-6, IL-8, or MCP-1 goes along with enhanced migration of monocytes to the site of injury, hereby promoting a pro-inflammatory response.

Hormones such as angiotensin-II or melatonin were used to pretreat MSCs before their use in in vivo models. Pretreatment of MSCs with angiotensin-II resulted in an improved cardiac function and a reduced occurrence of cardiac fibrosis, a smaller infarct size, and a higher expression of VEGF and von Willebrand factor in ischemic myocardium [103]. Another study examined the effect of melatonin pretreatment of MSCs in vivo after transplantation into the ischemic brain [104]. MSCs preconditioned with melatonin re- 
duced brain infarction, improved neurobehavioral outcomes, and showed increased angiogenesis and VEGF expression [104]. In addition, MSCs treated with melatonin displayed an increased expression of HGF and FGF-2 [105]. CM from melatonin-treated MSCs stimulated tube formation of endothelial progenitor cells and proliferation of renal proximal tubular cells in vitro. Moreover, the study showed that melatonin pretreatment strongly increased MSC survival after transplantation in a model of acute kidney injury. This effect was concomitant with an increased angiogenesis, proliferation of renal cells, and accelerated recovery of renal function [105].

\section{Preconditioning Regimens Using Pharmacological or Chemical Agents}

Alternative preconditioning concepts to prime MSCs in vitro prior to their use in in vivo models include pretreatment with atorvastatin, curcumin, and several other pharmacological or chemical agents.

Atorvastatin, a statin used as a lipid-lowering agent and for prevention of events associated with cardiovascular disease, enhanced the expression of CXC chemokine receptor 4 (CXCR4) on MSCs and stimulated MSC migration in vitro [106]. The significant role of SDF-1 and its receptor CXCR4 in mobilization and migration of MSCs to sites of injury has been elucidated $[90,107]$. Therefore, MSC pretreatment with atorvastatin was tested in an in vivo model of myocardial infarction [106]. Li et al. [106] found an increased migration and homing of MSCs toward the infarcted myocardium compared to non-pretreated MSCs and suggested that atorvastatin pretreatment is an effective preconditioning regimen to promote the cell-therapeutic potential of MSCs. In addition, enhanced regenerative efficacy of MSC transplantation has also been shown after MSC preconditioning with LPS [108]. LPS, an endotoxin of Gram-negative bacteria, is known as the ligand of Toll-like receptor-4, which is expressed by MSCs. In a model of myocardial infarction, LPS pretreatment ameliorated the cardiac function, reduced fibrosis, stimulated expression of VEGF, and activated the PI3K/Akt pathway [108].

Curcumin, an agent extracted from the spice turmeric, has been reported to show potent antioxidant and anti-inflammatory properties and free radical-scavenging activity [109]. A study by Liu et al. [109] showed that pretreatment of MSCs with curcumin improved the tolerance to oxidative stress injury and resulted in an enhancement of the therapeutic potential of MSCs in myocardial repair after infarction.

Pharmacological MSC preconditioning with diazoxide, a mitochondrial ATP-sensitive potassium channel opener, protected cells from oxidative stress injury by upregulating the expression of FGF-2 and HGF [110]. In an in vivo model of myocardial infarction, diazoxide preconditioning improved the survival rate of the infused MSCs, reduced the infarct size, and increased left ventricular function compared to the transplantation of non-pretreated MSCs [110].
Preconditioning with deferoxamine, an iron-chelating drug, stabilized HIF-1 $\alpha$ under normoxic conditions as well as the activity of two metalloproteases [111]. Notably, the stabilization of HIF-1a resulted in an increased activity as well as in increased transcription of genes involved in cell migration [112]. Deferoxamine preconditioning prior to transplantation also increased homing of MSCs through affecting chemokine receptors as well as metalloproteases [111].

ROS and reactive nitrogen species are biologically active oxidants and are regarded as important physiological signaling molecules. Various reports indicate the role of ROS as second messengers in the $\mathrm{O}_{2}$ sensing $[113,114]$. In a previous study, ROS preconditioning has been shown to enhance the pro-angiogenic properties of MSCs [114]. Applying a pharmacological preconditioning strategy with the mitochondrial inhibitors antimycin and rotenone to modulate ROS generation in MSCs, the authors found that this regimen strongly improved revascularization and the number of MSC-derived CD31+ cells in the ischemic area. Furthermore, ROS generation increased MSC secretion of the pro-angiogenic and anti-apoptotic factors VEGF and HGF, but did not affect the ability of MSCs to differentiate into cells with endothelial phenotype in vitro [114].

Another study showed that MSC preconditioning with valproat and lithium chloride promoted functional recovery, increased angiogenesis, and reduced the infarcted zone in the brain in a rat cerebral artery occlusion model [115]. Additionally, increased migration and homing of MSCs towards the ischemic site, possibly mediated by an increased CXCR4 expression, was observed [115].

\section{And What about Current Clinical Studies on MSC Preconditioning Therapies?}

As mentioned above, recent data clearly indicate that a functional improvement of the regenerative capacities of MSCs could be obtained by applying different MSC preconditioning regimens in vitro and after MSC infusion in different in vivo models. Clinical trials using MSCs have been expanding quickly in the last decade. However, although various MSCs preconditioning strategies have been developed and have been already evaluated in animal models, currently only three clinical trials are registered on www.clinicaltrials.gov (table 3). All three clinical studies use a comparable (but not equal) preconditioning regimen (hypoxia, ischemic preconditioning) for in vitro pretreatment of BM-MSCs; three different pathologies have been investigated (table 3). The purpose of the first study is to evaluate the efficacy of hypoxia-preconditioned autologous BM-MSCs for patients with ischemic heart diseases. The second study examines the regeneration of the lung in patients suffering from pulmonary emphysema after transplantation of hypoxia-preconditioned autologous BM-MSCs. Currently, only these two studies are listed on $w w w$.clinicaltrials.gov, and the study protocol of the third study was published in a scientific journal [116]. The objective of this study is to evaluate the efficacy of preconditioned MSCs in patients with ischemic stroke. The chosen pretreatment ('ischemic 
Table 3. Current clinical trials using MSCs after preconditioning to enhance their therapeutic efficacy (www.clinicaltrials.gov).

\begin{tabular}{|c|c|}
\hline Study & Identifier \\
\hline $\begin{array}{l}\text { The STem Cell Application Researches and Trials In NeuroloGy-2 } \\
\text { (STARTING-2) Study [116] } \\
\text { Condition: Stroke, ischemic } \\
\text { Intervention: Transplantation of autologous BM-MSCs preconditioned with autologous serum } \\
\text { obtained at acute phase of stroke ('ischemic preconditioning') } \\
\text { Study start date: November } 2012\end{array}$ & NCT01716481 \\
\hline $\begin{array}{l}\text { Clinical Study of the Efficacy and Safety of the Application of Allogeneic Mesenchymal (Stromal) } \\
\text { Cells of Bone Marrow, Cultured Under the Hypoxia in the Treatment of Patients With Severe } \\
\text { Pulmonary Emphysema } \\
\text { Condition: Pulmonary emphysema } \\
\text { Intervention: Infusion of allogeneic BM-MSCs, in vitro preconditioned } \\
\text { under 1\% hypoxia } \\
\text { Study start date: March } 2014\end{array}$ & NCT01849159 \\
\hline $\begin{array}{l}\text { Therapy of Preconditioned Autologous BMMSCs for Patients with } \\
\text { Ischemic Heart Disease } \\
\text { Conditions: Acute myocardial infarction; ischemic cardiomyopathy } \\
\text { Intervention: Transplantation of autologous BM-MSCs with hypoxia precondition and endothelial } \\
\text { preinduction } \\
\text { Study start date: November } 2015\end{array}$ & NCT02504437 \\
\hline
\end{tabular}

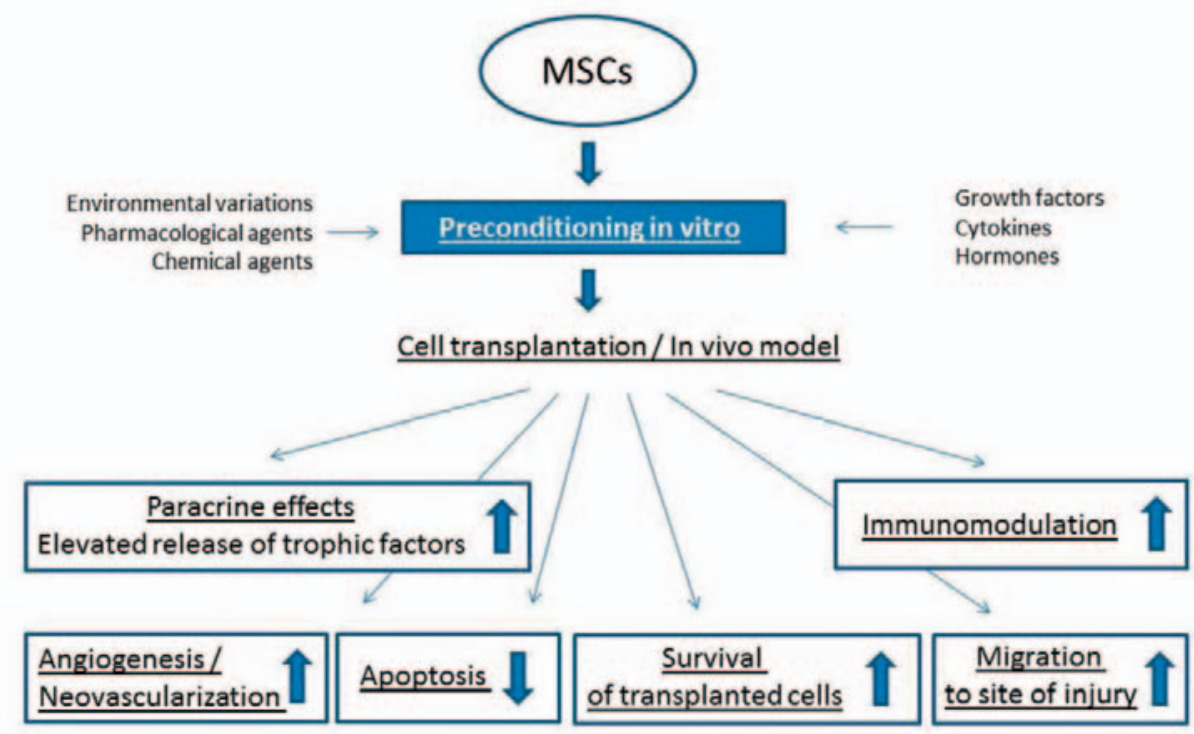

Fig. 1. Mechanisms involved in the enhanced therapeutic potential of preconditioned MSCs. optimize the regenerative capacity of MSCs (or their CM), more clinical trials investigating the effects of different preconditioning regimens in varying pathological situations are urgently needed.

\section{Final Remarks}

In summary, transplantation of preconditioned MSCs has shown promising results. Whereas not finally proven, it seems clear that manifold mechanisms are involved in the increased benefit of cell therapy using preconditioned MSCs (fig. 1). As shown by numerous experimental studies reviewed in this article, the enhancement of the therapeutic potential of MSCs by precondition- 
ing is mediated by a great variety of mechanisms at which enhancement of paracrine factors release by pretreated MSCs appears as highly relevant mechanism. Nevertheless, other events are likely involved, such as upregulation of different surface proteins/receptors or enhanced survival of transplanted cells. The complete effects and the whole secretome of MSCs after different preconditioning regimens have not been investigated in a comprehensive manner yet. Advances in high-throughput technologies, protein and RNA arrays, and bioinformatics have already facilitated analysis of the secretome including EVs and will continue to help identifying the factors released by MSCs under different precondition regimens [81]. In addition, data from different in vivo models are often conflicting and hampered by varying MSC isolation protocols, culture or proliferation methods, preconditioning regimen and schedule, application sites, and numbers of transplanted MSCs [59]. To date, methods for in vitro pretreatment or preconditioning, possibly by combination of factors, have not been optimized to improve MSCs or their conditioned medium-based therapies, and, therefore, need to be substantially improved in future works.

A huge gap between experimental approaches and their application is observed in the clinic. To date, clinical studies confirming the preclinical results are missing. Thus, additional research using in vivo studies to determine the exact underlying mechanisms and, in particular, clinical trials to show the regenerative efficacy and the benefit of preconditioned MSCs are required and are expected in future years. Nevertheless, encouraging preclinical studies fuel the hope that preconditioning regimens can enhance the regenerative capacities of MSC therapies.

\section{Disclosure Statement}

The authors declare no conflict of interest.

\section{References}

1 Friedenstein AJ, Petrakova KV, Kurolesova AI, Frolova GP: Heterotopic of bone marrow. Analysis of precursor cells for osteogenic and hematopoietic tissues. Transplantation 1968;6:230-247.

2 Friedenstein AJ, Chailakhyan RK, Latsinik NV, Panasyuk AF, Keiliss-Borok IV: Stromal cells responsible for transferring the microenvironment of the hemopoietic tissues. Cloning in vitro and retransplantation in vivo. Transplantation 1974;17:331-340.

3 da Silva ML, Chagastelles PC, Nardi NB: Mesenchymal stem cells reside in virtually all post-natal organs and tissues. J Cell Sci 2006;119:2204-2213.

4 Murray IR, Peault B: Q\&A: Mesenchymal stem cells where do they come from and is it important? BMC Biol 2015;13:99.

5 Kim YS, Lee HJ, Yeo JE, Kim YI, Choi YJ, Koh YG: Isolation and characterization of human mesenchymal stem cells derived from synovial fluid in patients with osteochondral lesion of the talus. Am J Sports Med 2015;43:399-406.

6 Kern S, Eichler H, Stoeve J, Kluter H, Bieback K: Comparative analysis of mesenchymal stem cells from bone marrow, umbilical cord blood, or adipose tissue. Stem Cells 2006;24:1294-1301.

7 De Coppi P, Bartsch G Jr, Siddiqui MM, Xu T, Santos CC, Perin L, Mostoslavsky G, Serre AC, Snyder EY, Yoo JJ, Furth ME, Soker S, Atala A: Isolation of amniotic stem cell lines with potential for therapy. Nat Biotechnol 2007;25:100-106.

8 Dominici M, Le Blanc K, Mueller I, Slaper-Cortenbach I, Marini F, Krause D, Deans R, Keating A, Prockop D, Horwitz E: Minimal criteria for defining multipotent mesenchymal stromal cells. The International Society for Cellular Therapy position statement. Cytotherapy 2006;8:315-317.

9 Chamberlain G, Fox J, Ashton B, Middleton J: Concise review: mesenchymal stem cells: their phenotype, differentiation capacity, immunological features, and potential for homing. Stem Cells 2007;25:2739-2749.
Kawada H, Fujita J, Kinjo K, Matsuzaki Y, Tsuma M, Miyatake H, Muguruma Y, Tsuboi K, Itabashi Y, Ikeda Y, Ogawa S, Okano H, Hotta T, Ando K, Fukuda K: Nonhematopoietic mesenchymal stem cells can be mobilized and differentiate into cardiomyocytes after myocardial infarction. Blood 2004;104:3581-3587.

11 Fukuda K: Development of regenerative cardiomyocytes from mesenchymal stem cells for cardiovascular tissue engineering. Artif Organs 2001;25:187-193.

12 Silva GV, Litovsky S, Assad JA, Sousa AL, Martin BJ, Vela D, Coulter SC, Lin J, Ober J, Vaughn WK, Branco RV, Oliveira EM, He R, Geng YJ, Willerson JT, Perin EC: Mesenchymal stem cells differentiate into an endothelial phenotype, enhance vascular density, and improve heart function in a canine chronic ischemia model. Circulation 2005;111:150-156.

13 Gang EJ, Jeong JA, Hong SH, Hwang SH, Kim SW, Yang IH, Ahn C, Han H, Kim H: Skeletal myogenic differentiation of mesenchymal stem cells isolated from human umbilical cord blood. Stem Cells 2004;22: 617-624.

14 Wakitani S, Saito T, Caplan AI: Myogenic cells derived from rat bone marrow mesenchymal stem cells exposed to 5-azacytidine. Muscle Nerve 1995;18:14171426.

15 Ortiz LA, Gambelli F, McBride C, Gaupp D, Baddoo M, Kaminski N, Phinney DG: Mesenchymal stem cell engraftment in lung is enhanced in response to bleomycin exposure and ameliorates its fibrotic effects. Proc Natl Acad Sci U S A 2003;100:8407-8411.

16 Spees JL, Olson SD, Ylostalo J, Lynch PJ, Smith J, Perry A, Peister A, Wang MY, Prockop DJ: Differentiation, cell fusion, and nuclear fusion during ex vivo repair of epithelium by human adult stem cells from bone marrow stroma. Proc Natl Acad Sci U S A 2003;100:23972402.

17 Kopen GC, Prockop DJ, Phinney DG: Marrow stromal cells migrate throughout forebrain and cerebellum, and they differentiate into astrocytes after injection into neonatal mouse brains. Proc Natl Acad Sci U S A 1999;96:10711-10716.
18 Pacary E, Legros H, Valable S, Duchatelle P, Lecocq M Petit E, Nicole O, Bernaudin M: Synergistic effects of $\mathrm{CoCl}(2)$ and ROCK inhibition on mesenchymal stem cell differentiation into neuron-like cells. J Cell Sci 2006;119:2667-2678.

19 Phinney DG, Prockop DJ: Concise review: mesenchymal stem/multipotent stromal cells: the state of transdifferentiation and modes of tissue repair - current views. Stem Cells 2007;25:2896-2902.

20 Rose RA, Jiang H, Wang X, Helke S, Tsoporis JN, Gong N, Keating SC, Parker TG, Backx PH, Keating A: Bone marrow-derived mesenchymal stromal cells express cardiac-specific markers, retain the stromal phenotype, and do not become functional cardiomyocytes in vitro. Stem Cells 2008;26:2884-2892.

21 Siegel G, Krause P, Wohrle S, Nowak P, Ayturan M, Kluba T, Brehm BR, Neumeister B, Kohler D, Rosenberger P, Just L, Northoff H, Schafer R: Bone marrowderived human mesenchymal stem cells express cardiomyogenic proteins but do not exhibit functional cardiomyogenic differentiation potential. Stem Cells Dev 2012;21:2457-2470.

22 Hanabusa K, Nagaya N, Iwase T, Itoh T, Murakami S, Shimizu Y, Taki W, Miyatake K, Kangawa K: Adrenomedullin enhances therapeutic potency of mesenchymal stem cells after experimental stroke in rats. Stroke 2005;36:853-858.

23 Williams AR, Hare JM: Mesenchymal stem cells: biology, pathophysiology, translational findings, and therapeutic implications for cardiac disease. Circ Res 2011; 109:923-940.

24 Lee RH, Seo MJ, Reger RL, Spees JL, Pulin AA, Olson SD, Prockop DJ: Multipotent stromal cells from human marrow home to and promote repair of pancreatic islets and renal glomeruli in diabetic NOD/scid mice. Proc Natl Acad Sci U S A 2006;103:17438-17443.

25 Le Blanc K, Rasmusson I, Sundberg B, Gotherstrom C, Hassan M, Uzunel M, Ringden O: Treatment of severe acute graft-versus-host disease with third party haploidentical mesenchymal stem cells. Lancet 2004;363: 1439-1441. 
26 Le Blanc K, Samuelsson H, Gustafsson B, Remberger $\mathrm{M}$, Sundberg B, Arvidson J, Ljungman P, Lonnies $\mathrm{H}$, Nava S, Ringden O: Transplantation of mesenchymal stem cells to enhance engraftment of hematopoietic stem cells. Leukemia 2007;21:1733-1738.

27 Le Blanc K, Frassoni F, Ball L, Locatelli F, Roelofs H, Lewis I, Lanino E, Sundberg B, Bernardo ME, Remberger M, Dini G, Egeler RM, Bacigalupo A, Fibbe W, Ringden O: Mesenchymal stem cells for treatment of steroid-resistant, severe, acute graft-versus-host disease: a phase II study. Lancet 2008;371:1579-1586.

28 Ringden O, Uzunel M, Rasmusson I, Remberger M, Sundberg B, Lonnies H, Marschall HU, Dlugosz A, Szakos A, Hassan Z, Omazic B, Aschan J, Barkholt L, Le BK: Mesenchymal stem cells for treatment of therapy-resistant graft-versus-host disease. Transplantation 2006;81:1390-1397.

29 Horwitz EM, Gordon PL, Koo WK, Marx JC, Neel MD, McNall RY, Muul L, Hofmann T: Isolated allogeneic bone marrow-derived mesenchymal cells engraft and stimulate growth in children with osteogenesis imperfecta: implications for cell therapy of bone. Proc Natl Acad Sci U S A 2002;99:8932-8937.

30 Rasini V, Dominici M, Kluba T, Siegel G, Lusenti G, Northoff H, Horwitz EM, Schafer R: Mesenchymal stromal/stem cells markers in the human bone marrow. Cytotherapy 2013;15:292-306.

31 Crisan M, Yap S, Casteilla L, Chen CW, Corselli M, Park TS, Andriolo G, Sun B, Zheng B, Zhang L, Norotte C, Teng PN, Traas J, Schugar R, Deasy BM, Badylak S, Buhring HJ, Giacobino JP, Lazzari L, Huard J, Peault B: A perivascular origin for mesenchymal stem cells in multiple human organs. Cell Stem Cell 2008;3:301-313.

32 Churchman SM, Ponchel F, Boxall SA, Cuthbert R, Kouroupis D, Roshdy T, Giannoudis PV, Emery P, McGonagle D, Jones EA: Transcriptional profile of native CD271+ multipotential stromal cells: evidence for multiple fates, with prominent osteogenic and Wnt pathway signaling activity. Arthritis Rheum 2012;64: 2632-2643.

- 33 Siegel G, Kluba T, Hermanutz-Klein U, Bieback K, Northoff H, Schafer R: Phenotype, donor age and gender affect function of human bone marrow-derived mesenchymal stromal cells. BMC Med 2013;11:146.

34 Schafer R, Dominici M, Muller I, Dazzi F, Bieback K, Godthardt K, Blanc KL, Meisel R, Pochampally R, Richter R, Skutella T, Steinhoff G, Mitterberger M, Wendel H, Wiskirchen J, Handgretinger R, Northoff $\mathrm{H}$ : Progress in characterization, preparation and clinical applications of non-hematopoietic stem cells, 29-30 September 2006, Tubingen, Germany. Cytotherapy 2007;9:397-405.

35 Jones E, Schafer R: Biological differences between native and cultured mesenchymal stem cells: implications for therapies. Methods Mol Biol 2015;1235:105-120.

-36 Baer PC, Kuci S, Krause M, Kuci Z, Zielen S, Geiger H, Bader P, Schubert R: Comprehensive phenotypic characterization of human adipose-derived stromal/stem cells and their subsets by a high throughput technology. Stem Cells Dev 2013;22:330-339.

37 Kocaoemer A, Kern S, Kluter H, Bieback K: Human $\mathrm{AB}$ serum and thrombin-activated platelet-rich plasma are suitable alternatives to fetal calf serum for the expansion of mesenchymal stem cells from adipose tissue. Stem Cells 2007;25:1270-1278.

38 Bieback K, Hecker A, Kocaomer A, Lannert H, Schallmoser K, Strunk D, Kluter H: Human alternatives to fetal bovine serum for the expansion of mesenchymal stromal cells from bone marrow. Stem Cells 2009;27: 2331-2341.
39 Brun J, Abruzzese T, Rolauffs B, Aicher WK, Hart ML: Choice of xenogenic-free expansion media significantly influences the myogenic differentiation potential of human bone marrow-derived mesenchymal stromal cells. Cytotherapy 2016;18:344-359.

40 Danielyan L, Schafer R, Schulz A, Ladewig T, Lourhmati A, Buadze M, Schmitt AL, Verleysdonk S, Kabisch D, Koeppen K, Siegel G, Proksch B, Kluba T, Eckert A, Kohle C, Schoneberg T, Northoff H, Schwab $\mathrm{M}$, Gleiter $\mathrm{CH}$ : Survival, neuron-like differentiation and functionality of mesenchymal stem cells in neurotoxic environment: the critical role of erythropoietin. Cell Death Differ 2009;16:1599-1614.

41 Schafer R: Does the adult stroma contain stem cells? Adv Biochem Eng Biotechnol 2013;129:177-189.

42 Muraglia A, Cancedda R, Quarto R: Clonal mesenchymal progenitors from human bone marrow differentiate in vitro according to a hierarchical model. J Cell Sci 2000;113:1161-1166.

43 Ragni E, Montemurro T, Montelatici E, Lavazza C, Vigano M, Rebulla P, Giordano R, Lazzari L: Differential microRNA signature of human mesenchymal stem cells from different sources reveals an 'environmentalniche memory' for bone marrow stem cells. Exp Cell Res 2013;319:1562-1574.

44 Pilz GA, Ulrich C, Ruh M, Abele H, Schafer R, Kluba T, Buhring HJ, Rolauffs B, Aicher WK: Human term placenta-derived mesenchymal stromal cells are less prone to osteogenic differentiation than bone marrowderived mesenchymal stromal cells. Stem Cells Dev 2011;20:635-646.

45 Henrich D, Nau C, Kraft SB, Zollfrank M, Kontradowitz K, Oppermann E, Schultheiss J, Meier S, Frank J, Marzi I, Seebach C: Effect of the harvest procedure and tissue site on the osteogenic function of and gene expression in human mesenchymal stem cells. Int J Mol Med 2016;37:976-988.

46 Beane OS, Darling EM: Isolation, characterization, and differentiation of stem cells for cartilage regeneration. Ann Biomed Eng 2012;40:2079-2097.

47 Pievani A, Scagliotti V, Russo FM, Azario I, Rambaldi B, Sacchetti B, Marzorati S, Erba E, Giudici G, Riminucci M, Biondi A, Vergani P, Serafini M: Comparative analysis of multilineage properties of mesenchymal stromal cells derived from fetal sources shows an advantage of mesenchymal stromal cells isolated from cord blood in chondrogenic differentiation potential. Cytotherapy 2014;16:893-905.

48 Karlupia N, Manley NC, Prasad K, Schafer R, Steinberg GK: Intraarterial transplantation of human umbilical cord blood mononuclear cells is more efficacious and safer compared with umbilical cord mesenchymal stromal cells in a rodent stroke model. Stem Cell Res Ther 2014;5:45.

49 Walmsley GG, Atashroo DA, Maan ZN, Hu MS, Zielins ER, Tsai JM, Duscher D, Paik K, Tevlin R, Marecic O, Wan DC, Gurtner GC, Longaker MT: High-throughput screening of surface marker expression on undifferentiated and differentiated human adipose-aerived stromal cells. Tissue Eng Part A 2015;21:2281-2291.

50 Boregowda SV, Krishnappa V, Haga CL, Ortiz LA, Phinney DG: A clinical indications prediction scale based on TWIST1 for human mesenchymal stem cells. EBioMedicine 2016;4:62-73.

51 Cox G, Boxall SA, Giannoudis PV, Buckley CT, Roshdy T, Churchman SM, McGonagle D, Jones E: High abundance of CD271(+) multipotential stromal cells (MSCs) in intramedullary cavities of long bones. Bone 2012;50:510-517.
2 Cuthbert RJ, Giannoudis PV, Wang XN, Nicholson L, Pawson D, Lubenko A, Tan HB, Dickinson A, McGonagle D, Jones E: Examining the feasibility of clinical grade CD271+ enrichment of mesenchymal stromal cells for bone regeneration. PLoS ONE 2015; 10:e117855.

53 Ulrich C, Abruzzese T, Maerz JK, Ruh M, Amend B, Benz K, Rolauffs B, Abele H, Hart ML, Aicher WK: Human placenta-derived CD146-positive mesenchymal stromal cells display a distinct osteogenic differentiation potential. Stem Cells Dev 2015;24:1558-1569.

54 Samsonraj RM, Rai B, Sathiyanathan P, Puan KJ, Rotzschke O, Hui JH, Raghunath M, Stanton LW, Nurcombe V, Cool SM: Establishing criteria for human mesenchymal stem cell potency. Stem Cells 2015;33: 1878-1891.

55 Duscher D, Rennert RC, Januszyk M, Anghel E, Maan ZN, Whittam AJ, Perez MG, Kosaraju R, Hu MS, Walmsley GG, Atashroo D, Khong S, Butte AJ, Gurtner GC: Aging disrupts cell subpopulation dynamics and diminishes the function of mesenchymal stem cells. Sci Rep 2014;4:7144.

56 Rennert RC, Schafer R, Bliss T, Januszyk M, Sorkin M, Achrol AS, Rodrigues M, Maan ZN, Kluba T, Steinberg GK, Gurtner GC: High-resolution microfluidic single-cell transcriptional profiling reveals clinically relevant subtypes among human stem cell populations commonly utilized in cell-based therapies. Front Neurol 2016;7:41.

57 Iso Y, Spees JL, Serrano C, Bakondi B, Pochampally R, Song YH, Sobel BE, Delafontaine P, Prockop DJ: Multipotent human stromal cells improve cardiac function after myocardial infarction in mice without long-term engraftment. Biochem Biophys Res Commun 2007;354: 700-706.

58 Caplan AI, Dennis JE: Mesenchymal stem cells as trophic mediators. J Cell Biochem 2006;98:1076-1084.

59 Doorn J, Moll G, Le BK, van BC, de BJ: Therapeutic applications of mesenchymal stromal cells: paracrine effects and potential improvements. Tissue Eng Part B Rev 2012;18:101-115.

60 Mirotsou M, Zhang Z, Deb A, Zhang L, Gnecchi M, Noiseux N, Mu H, Pachori A, Dzau V: Secreted frizzled related protein 2 (Sfrp2) is the key Akt-mesenchymal stem cell-released paracrine factor mediating myocardial survival and repair. Proc Natl Acad Sci U S A 2007;104:1643-1648.

61 Hsiao ST, Asgari A, Lokmic Z, Sinclair R, Dusting GJ Lim SY, Dilley RJ: Comparative analysis of paracrine factor expression in human adult mesenchymal stem cells derived from bone marrow, adipose, and dermal tissue. Stem Cells Dev 2012;21:2189-2203.

62 Kurozumi K, Nakamura K, Tamiya T, Kawano Y, Ishii K, Kobune M, Hirai S, Uchida H, Sasaki K, Ito Y, Kato K, Honmou O, Houkin K, Date I, Hamada H: Mesenchymal stem cells that produce neurotrophic factors reduce ischemic damage in the rat middle cerebral artery occlusion model. Mol Ther 2005;11:96-104.

63 Kurozumi K, Nakamura K, Tamiya T, Kawano Y, Kobune M, Hirai S, Uchida H, Sasaki K, Ito Y, Kato K, Honmou O, Houkin K, Date I, Hamada H: BDNF gene-modified mesenchymal stem cells promote functional recovery and reduce infarct size in the rat middle cerebral artery occlusion model. Mol Ther 2004;9: 189-197.

64 Nomura T, Honmou O, Harada K, Houkin K, Hamada $\mathrm{H}$, Kocsis JD: I.V. infusion of brain-derived neurotrophic factor gene-modified human mesenchymal stem cells protects against injury in a cerebral ischemia model in adult rat. Neuroscience 2005;136:161-169. 
65 Schafer R, Northoff H: Cardioprotection and cardiac regeneration by mesenchymal stem cells. Panminerva Med 2008;50:31-39.

66 Rani S, Ryan AE, Griffin MD, Ritter T: Mesenchymal stem cell-derived extracellular vesicles: toward cell-free therapeutic applications. Mol Ther 2015;23:812-823.

67 Konala VB, Mamidi MK, Bhonde R, Das AK, Pochampally R, Pal R: The current landscape of the mesenchymal stromal cell secretome: a new paradigm for cellfree regeneration. Cytotherapy 2016;18:13-24.

68 Akyurekli C, Le Y, Richardson RB, Fergusson D, Tay J, Allan DS: A systematic review of preclinical studies on the therapeutic potential of mesenchymal stromal cellderived microvesicles. Stem Cell Rev 2015;11:150-160.

69 Rani S, Ritter T: The exosome - a naturally secreted nanoparticle and its application to wound healing. Adv Mater 2015; doi: 10.1002/adma.201504009.

70 Yang JX, Zhang N, Wang HW, Gao P, Yang QP, Wen QP: CXCR4 receptor overexpression in mesenchymal stem cells facilitates treatment of acute lung injury in rats. J Biol Chem 2015;290:1994-2006.

71 Zhao SL, Zhang YJ, Li MH, Zhang XL, Chen SL: Mesenchymal stem cells with overexpression of midkine enhance cell survival and attenuate cardiac dysfunction in a rat model of myocardial infarction. Stem Cell Res Ther 2014;5:37.

72 Madonna R, Taylor DA, Geng YJ, De CR, Shelat H, Perin EC, Willerson JT: Transplantation of mesenchymal cells rejuvenated by the overexpression of telomerase and myocardin promotes revascularization and tissue repair in a murine model of hindlimb ischemia. Circ Res 2013;113:902-914.

73 Wang X, Zhao T, Huang W, Wang T, Qian J, Xu M, Kranias EG, Wang Y, Fan GC: Hsp20-engineered mesenchymal stem cells are resistant to oxidative stress via enhanced activation of Akt and increased secretion of growth factors. Stem Cells 2009;27:3021-3031.

74 Angoulvant D, Fazel S, Weisel RD, Lai TY, Fedak PW, Chen L, Rafati S, Seneviratne CK, Degousee N, Li RK: Cell-based gene therapy modifies matrix remodeling after a myocardial infarction in tissue inhibitor of matrix metalloproteinase-3-deficient mice. J Thorac Cardiovasc Surg 2009;137:471-480.

75 Rosova I, Dao M, Capoccia B, Link D, Nolta JA: Hypoxic preconditioning results in increased motility and improved therapeutic potential of human mesenchymal stem cells. Stem Cells 2008;26:2173-2182.

76 Hu X, Yu SP, Fraser JL, Lu Z, Ogle ME, Wang JA, Wei $\mathrm{L}$ : Transplantation of hypoxia-preconditioned mesenchymal stem cells improves infarcted heart function via enhanced survival of implanted cells and angiogenesis. J Thorac Cardiovasc Surg 2008;135:799-808.

77 Zhang W, Liu L, Huo Y, Yang Y, Wang Y: Hypoxiapretreated human MSCs attenuate acute kidney injury through enhanced angiogenic and antioxidative capacities. Biomed Res Int 2014;2014:462472.

78 Overath JM, Gauer S, Obermuller N, Schubert R, Schafer R, Geiger H, Baer PC: Short-term preconditioning enhances the therapeutic potential of adiposederived stromal/stem cell-conditioned medium in cisplatin-induced acute kidney injury. Exp Cell Res 2016; 342:175-183.

79 Li JH, Zhang N, Wang JA: Improved anti-apoptotic and anti-remodeling potency of bone marrow mesenchymal stem cells by anoxic pre-conditioning in diabetic cardiomyopathy. J Endocrinol Invest 2008;31: 103-110.

80 Stubbs SL, Hsiao ST, Peshavariya HM, Lim SY, Dusting GJ, Dilley RJ: Hypoxic preconditioning enhances survival of human adipose-derived stem cells and conditions endothelial cells in vitro. Stem Cells Dev 2012; 21:1887-1896.
Beegle J, Lakatos K, Kalomoiris S, Stewart H, Isseroff RR, Nolta JA, Fierro FA: Hypoxic preconditioning of mesenchymal stromal cells induces metabolic changes, enhances survival, and promotes cell retention in vivo. Stem Cells 2015;33:1818-1828.

82 Kang S, Kim SM, Sung JH: Cellular and molecular stimulation of adipose-derived stem cells under hypoxia. Cell Biol Int 2014;38:553-562.

83 Ceradini DJ, Kulkarni AR, Callaghan MJ, Tepper OM, Bastidas N, Kleinman ME, Capla JM, Galiano RD, Levine JP, Gurtner GC: Progenitor cell trafficking is regulated by hypoxic gradients through HIF-1 induction of SDF-1. Nat Med 2004;10:858-864

84 Bruno S, Grange C, Collino F, Deregibus MC, Cantaluppi V, Biancone L, Tetta C, Camussi G: Microvesicles derived from mesenchymal stem cells enhance survival in a lethal model of acute kidney injury. PLoS ONE 2012;7:e33115.

85 Chistiakov DA, Chekhonin VP: Extracellular vesicles shed by glioma cells: pathogenic role and clinical value. Tumour Biol 2014;35:8425-8438.

86 Quesenberry PJ, Goldberg LR, Aliotta JM, Dooner MS, Pereira MG, Wen S, Camussi G: Cellular phenotype and extracellular vesicles: basic and clinical considerations. Stem Cells Dev 2014;23:1429-1436.

87 Uemura R, Xu M, Ahmad N, Ashraf M: Bone marrow stem cells prevent left ventricular remodeling of ischemic heart through paracrine signaling. Circ Res 2006;98:1414-1421.

88 Bartosh TJ, Ylostalo JH, Mohammadipoor A, Bazhanov N, Coble K, Claypool K, Lee RH, Choi H, Prockop DJ: Aggregation of human mesenchymal stromal cells (MSCs) into 3D spheroids enhances their antiinflammatory properties. Proc Natl Acad Sci U S A 2010;107:13724-13729.

89 Ylostalo JH, Bartosh TJ, Tiblow A, Prockop DJ: Unique characteristics of human mesenchymal stro$\mathrm{mal} /$ progenitor cells pre-activated in 3-dimensional cultures under different conditions. Cytotherapy 2014; 16:1486-1500.

90 Pasha Z, Wang Y, Sheikh R, Zhang D, Zhao T, Ashraf $\mathrm{M}$ : Preconditioning enhances cell survival and differentiation of stem cells during transplantation in infarcted myocardium. Cardiovasc Res 2008;77:134-142.

91 Hahn JY, Cho HJ, Kang HJ, Kim TS, Kim MH, Chung JH, Bae JW, Oh BH, Park YB, Kim HS: Pre-treatment of mesenchymal stem cells with a combination of growth factors enhances gap junction formation, cytoprotective effect on cardiomyocytes, and therapeutic efficacy for myocardial infarction. J Am Coll Cardiol 2008;51:933-943.

92 Herrmann JL, Wang Y, Abarbanell AM, Weil BR, Tan J, Meldrum DR: Preconditioning mesenchymal stem cells with transforming growth factor-alpha improves mesenchymal stem cell-mediated cardioprotection. Shock 2010;33:24-30.

93 Rota C, Imberti B, Pozzobon M, Piccoli M, De CP, Atala A, Gagliardini E, Xinaris C, Benedetti V, Fabricio AS, Squarcina E, Abbate M, Benigni A, Remuzzi G, Morigi M: Human amniotic fluid stem cell preconditioning improves their regenerative potential. Stem Cells Dev 2012;21:1911-1923.

94 Xinaris C, Morigi M, Benedetti V, Imberti B, Fabricio AS, Squarcina E, Benigni A, Gagliardini E, Remuzzi G: A novel strategy to enhance mesenchymal stem cell migration capacity and promote tissue repair in an injury specific fashion. Cell Transplant 2013;22:423-436.

95 Heo SC, Jeon ES, Lee IH, Kim HS, Kim MB, Kim JH: Tumor necrosis factor-alpha-activated human adipose tissue-derived mesenchymal stem cells accelerate cutaneous wound healing through paracrine mechanisms. J Invest Dermatol 2011;131:1559-1567.
96 Xu B, Luo Y, Liu Y, Li BY, Wang Y: Platelet-derived growth factor-BB enhances MSC-mediated cardioprotection via suppression of miR-320 expression. Am J Physiol Heart Circ Physiol 2015;308:H980-H989.

97 Tamama K, Kawasaki H, Wells A: Epidermal growth factor (EGF) treatment on multipotential stromal cells (MSCs). Possible enhancement of therapeutic potential of MSC. J Biomed Biotechnol 2010;2010:795385.

98 Tamama K, Barbeau DJ: Early growth response genes signaling supports strong paracrine capability of mesenchymal stem cells. Stem Cells Int 2012;2012:428403.

99 Baer PC, Schubert R, Bereiter-Hahn J, Plosser M, Geiger $\mathrm{H}$ : Expression of a functional epidermal growth factor receptor on human adipose-derived mesenchymal stem cells and its signaling mechanism. Eur J Cell Biol 2009;88:273-283.

100 Tamama K, Fan VH, Griffith LG, Blair HC, Wells A: Epidermal growth factor as a candidate for ex vivo expansion of bone marrow-derived mesenchymal stem cells. Stem Cells 2006;24:686-695.

101 Kerpedjieva SS, Kim DS, Barbeau DJ, Tamama K: EGFR ligands drive multipotential stromal cells to produce multiple growth factors and cytokines via early growth response-1. Stem Cells Dev 2012;21:2541-2551.

102 Lee MJ, Kim J, Kim MY, Bae YS, Ryu SH, Lee TG, Kim JH: Proteomic analysis of tumor necrosis factor-alphainduced secretome of human adipose tissue-derived mesenchymal stem cells. J Proteome Res 2010;9:17541762.

103 Liu C, Fan Y, Zhou L, Zhu HY, Song YC, Hu L, Wang Y, Li QP: Pretreatment of mesenchymal stem cells with angiotensin II enhances paracrine effects, angiogenesis, gap junction formation and therapeutic efficacy for myocardial infarction. Int J Cardiol 2015;188:22-32.

104 Tang Y, Cai B, Yuan F, He X, Lin X, Wang J, Wang Y, Yang GY: Melatonin pretreatment improves the survival and function of transplanted mesenchymal stem cells after focal cerebral ischemia. Cell Transplant 2014; 23:1279-1291.

105 Mias C, Trouche E, Seguelas MH, Calcagno F, DignatGeorge F, Sabatier F, Piercecchi-Marti MD, Daniel L, Bianchi P, Calise D, Bourin P, Parini A, Cussac D: Ex vivo pretreatment with melatonin improves survival, proangiogenic/mitogenic activity, and efficiency of mesenchymal stem cells injected into ischemic kidney. Stem Cells 2008;26:1749-1757.

106 Li N, Yang YJ, Qian HY, Li Q, Zhang Q, Li XD, Dong QT, Xu H, Song L, Zhang H: Intravenous administration of atorvastatin-pretreated mesenchymal stem cells improves cardiac performance after acute myocardial infarction: role of CXCR4. Am J Transl Res 2015;7: 1058-1070.

107 Xu X, Zhu F, Zhang M, Zeng D, Luo D, Liu G, Cui W, Wang S, Guo W, Xing W, Liang H, Li L, Fu X, Jiang J, Huang H: Stromal cell-derived factor-1 enhances wound healing through recruiting bone marrow-derived mesenchymal stem cells to the wound area and promoting neovascularization. Cells Tissues Organs 2013;197:103-113.

108 Yao Y, Zhang F, Wang L, Zhang G, Wang Z, Chen J, Gao X: Lipopolysaccharide preconditioning enhances the efficacy of mesenchymal stem cells transplantation in a rat model of acute myocardial infarction. J Biomed Sci 2009;16:74.

109 Liu J, Zhu P, Song P, Xiong W, Chen H, Peng W, Wang S, Li S, Fu Z, Wang Y, Wang H: Pretreatment of adipose derived stem cells with curcumin facilitates myocardial recovery via antiapoptosis and angiogenesis. Stem Cells Int 2015;2015:638153. 
110 Cui X, Wang H, Guo H, Wang C, Ao H, Liu X, Tan YZ: Transplantation of mesenchymal stem cells preconditioned with diazoxide, a mitochondrial ATP-sensitive potassium channel opener, promotes repair of myocardial infarction in rats. Tohoku J Exp Med 2010;220: 139-147.

111 Najafi R, Sharifi AM: Deferoxamine preconditioning potentiates mesenchymal stem cell homing in vitro and in streptozotocin-diabetic rats. Expert Opin Biol Ther 2013;13:959-972.

112 Tsai CC, Yew TL, Yang DC, Huang WH, Hung SC: Benefits of hypoxic culture on bone marrow multipotent stromal cells. Am J Blood Res 2012;2:148-159.

113 Chandel NS, Maltepe E, Goldwasser E, Mathieu CE, Simon MC, Schumacker PT: Mitochondrial reactive oxygen species trigger hypoxia-induced transcription. Proc Natl Acad Sci U S A 1998;95:11715-11720.

114 Carriere A, Ebrahimian TG, Dehez S, Auge N, Joffre C, Andre M, Arnal S, Duriez M, Barreau C, Arnaud E, Fernandez Y, Planat-Benard V, Levy B, Penicaud L, Silvestre JS, Casteilla L: Preconditioning by mitochondrial reactive oxygen species improves the proangiogenic potential of adipose-derived cells-based therapy. Arterioscler Thromb Vasc Biol 2009;29:1093-1099.
115 Tsai LK, Wang Z, Munasinghe J, Leng Y, Leeds P, Chuang DM: Mesenchymal stem cells primed with valproate and lithium robustly migrate to infarcted regions and facilitate recovery in a stroke model. Stroke 2011;42:2932-2939.

116 Kim SJ, Moon GJ, Chang WH, Kim YH, Bang OY: Intravenous transplantation of mesenchymal stem cells preconditioned with early phase stroke serum: current evidence and study protocol for a randomized trial. Trials 2013;14:317.

117 Kim EH, Kim DH, Kim HR, Kim SY, Kim HH, Bang OY: Stroke serum priming modulates characteristics of mesenchymal stromal cells by controlling the expression miRNA-20a. Cell Transplant 2016; doi: 10.3727/ 096368916X690430

118 Amin AH, Abd Elmageed ZY, Nair D, Partyka MI, Kadowitz PJ, Belmadani S, Matrougui K: Modified multipotent stromal cells with epidermal growth factor restore vasculogenesis and blood flow in ischemic hindlimb of type II diabetic mice. Lab Invest 2010;90:985996.
119 Kim YS, Ahn Y, Kwon JS, Cho YK, Jeong MH, Cho JG, Park JC, Kang JC: Priming of mesenchymal stem cells with oxytocin enhances the cardiac repair in ischemia/ reperfusion injury. Cells Tissues Organs 2012;195:428442

120 Mastri M, Shah Z, McLaughlin T, Greene CJ, Baum L, Suzuki G, Lee T: Activation of Toll-like receptor 3 amplifies mesenchymal stem cell trophic factors and enhances therapeutic potency. Am J Physiol Cell Physiol 2012;303:C1021-C1033.

121 Zhang J, Chen GH, Wang YW, Zhao J, Duan HF, Liao LM, Zhang XZ, Chen YD, Chen H: Hydrogen peroxide preconditioning enhances the therapeutic efficacy of Wharton's Jelly mesenchymal stem cells after myocardial infarction. Chin Med J (Engl ) 2012;125:3472-3478.

122 Wisel S, Khan M, Kuppusamy ML, Mohan IK, Chacko SM, Rivera BK, Sun BC, Hideg K, Kuppusamy P: Pharmacological preconditioning of mesenchymal stem cells with trimetazidine (1-[2, 3, 4-trimethoxybenzyl] piperazine) protects hypoxic cells against oxidative stress and enhances recovery of myocardial function in infarcted heart through Bcl-2 expression. J Pharmacol Exp Ther 2009;329:543-550.

\section{Imprint}

ISSN Print Edition: $1660-3796$

ISSN Online Edition: 1660-3818

Journal Homepage: http://www.karger.com/tmh

Publication Data: Volume 43, 2016 of 'Transfusion Medicine and Therapy' appear with 6 issues.

Copyright: (c) 2016 by S. Karger Verlag für Medizin und Naturwissenschaften GmbH Freiburg (Germany). All rights reserved. No part of this publication may be translated into other languages, reproduced or utilized in any form or by any means, electronic or mechanical, including photocopying, recording, microcopying, or by any information storage and retrieval system, without permission in writing from the publisher or, in the case of photocoping, direct payment of a specified fee to the Copyright Clearance Center.

Photocopying: This journal has been registered with the Copyright Clearance Cente (CCC), as indicated by the code appearing on the first page of each article. For readers in the US, this code signals consent for copying of articles for personal or internal use, or for the personal or internal use of specific clients, provided that the stated fee is paid per copy directly to Copyright Clearance Center Inc., 222 Rosewood Drive, Danvers, MA 01923 (USA) A copy of the first page of the article must accompany payment. Consent does not extend to copying for general distribution, for promotion, for creating new works, or for resale. In these cases, specific written permission must be obtained from the copyright owner, S. Karger GmbH, Wilhelmstr. 20A, 79098 Freiburg (Germany).

Disclaimer: The statements, opinions and data contained in this publication are solely those of the individual authors and contributors and not of the publisher and the editor(s). The appearance of advertisements in the journal is not a warranty, endorsement, or approval of the products or services advertised or of their effectiveness, quality or safety. The publisher and the editor(s) disclaim responsibility for any injury to persons or property resulting form any ideas, methods, instructions or products referred to in the content or advertisements.

Subscription Rates: Subscriptions run for a full calendar year.

Prices are given per year.

Print:

Online:

EUR 185.00 + postage and handling

EUR 185.00

Combined (print+online): $\quad$ EUR 235.00 + postage and handling

Postage and handling (added to print and print+online):

EUR 19.00 (Germany), EUR 25.00 (Rest of World)

Discount subscription prices:

Please enquire about reduced rates for members of related societies
Back Volumes and Single Issues: Information on availability and prices of single print issues and print or electronic back volumes can be obtained from Customer Service at aboservice@karger.com

For customers in Germany: Please contact your local bookstore or

S. Karger Verlag für Medizin und Naturwissenschaften $\mathrm{GmbH}$

Wilhelmstr. 20A, 79098 Freiburg (Germany)

Tel. +497614520 70, Fax +497614520714

aboservice@karger.com

For customers in all other countries: Please contact your bookshop or S. Karger AG

Allschwilerstr. 10, 4009 Basel (Switzerland)

Tel. +416130611 11, Fax +41613061234

karger@karger.com

Advertising: Correspondence should be addressed to the publisher

S. Karger Verlag für Medizin und Naturwissenschaften $\mathrm{GmbH}$

Attn. Ellen Zimmermann (Head of Marketing)

e.zimmermann@karger.com

Price list No. 30 of January 1, 2016 is effective.

Publisher: S. Karger Verlag für Medizin und Naturwissenschaften GmbH Wilhelmstr. 20A, 79098 Freiburg (Germany)

www.karger.de, information@karger.com

V.i.S.d.P. (Person responsible according to the German Press Law): Sibylle Gross

Type setting and printing: Kraft Druck GmbH, 76275 Ettlingen, Germany. Printed on acid-free and non-aging paper (ISO 9706).

\section{Bibliographic Services}

Biological Abstracts / Current Contents/Clinical Medicine / Excerpta Medica/

EMBASE / Index Medicus/MEDLINE / Medical Documentation Service / Reference

Update / Research Alert / Science Citation Index / SCISEARCH Database / Scopus

\section{KARGER}

Fax +497614520714 Information@Karger.com www.karger.com

\section{๑) 2016 S. Karger GmbH, Freiburg}

Accessible online at:

www.karger.com/tmh 